\title{
MENGENALI IDENTITAS SANTUN BAHASA UMAT ALLAH DI INDONESIA
}

\author{
Hendarto Supatra \\ Fakultas Ilmu Budaya Universitas Diponegoro \\ anton.bowo.w@gmail.com
}

\begin{abstract}
Whatever the purpose, people talk or write, want to be noticed by P2. There are many ways to come into that goal, one among the others, is by trying to make his or her utterance amusing. Polite utterance makes others happy. Religion teaching on polite-ness or religion leader's (language) etiquette tend to become the sourse of patterns to follow. In the other hand, every language/culture society also has theirown rules of that language propriety. Then, it become interesting to search that kind of culture contact. This article trys to find out a set of possible principles based on that kind of contact between Christian etiquette and Indonesian language etiquette. It is hoped that the results can be used to determine the degree of politeness of Umat Allah.
\end{abstract}

Key words: linguistic etiquette, language propriety, receptor oriented, personalness

\section{Intisari}

Apa pun maksudnya, orang berbicara atau menulis tentu ingin diperhatikan. Ada banyak cara untuk mendapatkan tujuan itu, antara lain ialah dengan berusaha menyenangkan O2 dan O3. Tuturan yang santun itu menyenangkan. Salah satu sumber kesantunan adaLah ajaran agama atau keteladanan tokoh dalam agama tersebut. Sementara itu tiap-tiap masyarakat bahasa atau budaya tentu juga memiliki kekhasan santun bahasa. Hal nya menjadi menarik ketika etika bahasa yang bersumber dari tokoh agama bertemu dengan etika bahasa masyarakat bahasa/budaya tertentu. Artikel ini mencoba menemukan seperangkat prinsip dari perjumpaan antara etika komunikasi Kristen dengan etika bahasa Indonesia. Hasilnya diperkirakan bisa menjadi tolok ukur kesantunan dalam berkomunikasi, orang atau umat Kristen atau umat yang lain di Indonesia.

Kata Kunci: santun bahasa, orientasi pada lawan wicara, kepribadian

\section{Pendahuluan}

Santun bahasa atau language etiquette atau linguistic propriety adalah pokok bahasan yang bersangkutan dengan pilihan bentuk-bentuk bahasa yang mencerminkan kesantunan atau ketidaksantunan orang dalam bertutur kata atau lebih luas lagi dalam menjalin komunikasi dengan orang lain. Dikatakan lebih luas karena yang disebut terakhir itu meliputi baik 
komunikasi verbal maupun komunikasi nonverbal. Tuturan 'Silakan masuk' yang disertai dengan gerak tangan yang menunjuk ke a rah masuk, jelas lebih santun bila dibandingkan dengan ungkapan 'Masuk!' yang tidak disertai dengan gerak tubuh atau pun perubahan wajah yang menunjukkan keremahan. Nah ternyata soal keramahan itu memang tercermin dalam tindak komunikasi baik verbal maupun nonverbal; ada prinsip-prinsip tertentu yang melatarbelakanginya. Prinsip-prinsip macam apakah itu? Mungkinkah bertolak dari prinsipprinsip itu bisa diciptakan tolok ukur untuk menentukan kadar kesantunan seseorang atau suatu komunitas tutur? Tulisan ini mencoba menggali para meter semacam itu yang mudah-mudahan bisa menjadi dasar analisis data dalam suatu penelitian. Dengan kata lain di sini hendak dijajaki kemungkinan suatu aplikasi terori tentang santun bahasa (Indonesia) ke dalam sebuah metode penelitian.

Tulisan ini sengaja membatasi pokok kajian pada komunitas umat Allah. Umat Allah itu di sini meliputi komunitas beragama, baik Hindu, Budha, Islam, Kong Hu Chu, Kristen, dsb. Prinsip-prinsip santun bahasa atau santun komunikasi untuk umat Hindu tentu bersumber pada Kitab atau Kitab-kitab Suci Agama Hindu, untuk umat Budha ya tentu Kitab Tripitaka atau mungkin masih ada yang lain, untuk umat Islam atau kaum Muslimin ya Quran dan Hadith Nabi, untuk umat Kong Hu Chu Kitab Su Shi, dan untuk umat Kristen tentu saja Injil dan Tradisi Gereja. Meskipun di dalam tulisan ini contoh-contoh akan diambil dari umat Kristen berhubung penulis merasa paling beken sehingga data bisa diperoleh secara berlimpah dan dengan mudah, akan tetapi berdasarkan asumsi bahwa perihal kesopansantuan itu cenderung universal maka apa yang ditemukan atau terbukti dalam pengamatan penulis dan dilaporkan dalam tulisan ini bisa atau cenderung berlaku juga pada umat yang lain. Tentu saja ada juga yang khas Kristen namun ketika demikian halnya maka justru tulisan ini seharusnya mendorong untuk segera disusul dengan tulisan berikutnya dengan contoh-contoh yang spesifik juga: Hindu, Budha, Islam, atau pun Kong Hu Chu. Demi diperolehnya data dan penjelasan yang bersifat emik dan bukan etik maka penulis itu di samping peduli, juga memang betul-betul orang-dalam atau anggota dari komunitas yang dimaksud -Kristen.

Tulisan ini, jelas, normative sifatnya karena secara sadar penulis menggunakan sumber atau sumber-sumber tertentu yang sebenarnya berdasarkan keyakinan belaka. Hal yang demikian itu bukannya tidak, atau kurang bermanfaat sebab hasilnya, toh, diharapkan, bisa menjadi cermin bagi umat pada khususnya, maupun semua orang pada umumnya untuk melihat atau mengukur kadar keberhasilan orang dalam mengaplikasikan ajaran yang diyakini dan diikutinya ke dalam realitas hidup sehari-hari. Bukankah keimanan orang tampak atau malah 
seharusnya tampak dan bisa diukur dari relasinya terhadap sesama hidup. Aplikasi ajaran yang diklaimnya itu antara lain adalah ke dalam santun bahasa. Tentu saja kebermanfaatan itu juga berkaitan dengan pengembangan ilmu, baik sosiolinguistik maupun ilmu komunikasi. Sekaligus, dengan kata lain, di sini hendak dikatakan juga bahwa tulisan ini menggunakan kedua disiplin itu untuk menerangi pokok bahasan santun bahasa.

\section{Bahasa Menunjukkan Bangsa}

Ungkapan 'banasa menunjukkan bangsa'itu tepat sekali. Kecerdasan purba ini cocok benar dengan temuan para pakar sosiolinguistik yakni bahwa salah satu fungsi bahasa adalah sebagai identitas bangsa atau masyarakat penuturnya. Siapa pun Anda ketika pernah suatu saat tinggal dalam masyarakat yang multilingual atau multicultural akan sangat menyadari bahwa bahasa dan budaya (perilaku dan kebiasaan-kebiasaan tertentu) adalah ciri pengenal atau identitas Anda bersama-sama dengan orang-orang yang sebahasa dan sebudaya dengan Anda. Orang lain akan segera mengenali dan berkata 'Oh itu orang-orang Indonesia' karena Anda berbahasa Indonesia. Tentu saja ada juga orang-orang yang mahir berbahasa Indonesia bahkan menunjukkan gerak-gerik yang khas (budaya) Indonesia tetapi warga negara Belanda, Singapura, atau China.

Bahasa menunjukkan Bangsa tidak hanya memiliki makna harafiah dan sederhana seperti di atas. Secara metaforik, ungkapan itu berarti pula baik, biasa-biasa saja, kurang baik atau buruknya seseorang atau komunitas tertentu tercermin dalam tutur kata atau perbuatannya. Pendek kata ungkapan itu sering juga merupakan pepatah, untuk memuji (admire) atau mengritik (criticize) orang atau komunitas tertentu (Bandingkan Martin and Rose 2003: 30). Di awal era Reformasi, paruh kedua decade 90-an, ungkapan itu sering diplesetkan menjadi bahasa menunjukkan bangsat. Sebenarnya ini bukan semata-mata plesetan demi timbulnya efek lucu melainkan sebuah kritik atau malah caci maki (condemn) terhadap rejim yang telah memerintah secara totaliter dan membawa bangsa ini ke kubangan hutang internasional yang sangat berat.

Makna yang ketiga sehubungan dengan bahasa menunjukkan bangsa adalah makna yang dikenali lewat kajian sosiolingistik. Sosiolinguistik atau sociolinguistics adalah ' the study of language in relation to social factors, that is social class, educational level and type of education, age, sex, athnic origin, ets' (Richard, Platt, and Weber 1985: 262). Demikianlah bahwa realitas bahasa seseorang atau komunitas tertentu mencerminkan atau dipengaruhi oleh berbagai factor social yang adalah latar belakangnya: kelas social, pendidikan, umur, jenis 
kelamin, etnis, suku, ideology yang mencakupi agama juga. Dalam hal ini istilah bahasa pada ' bahasa menunjukkan bangsa' lebih merujuk pada dialek atau lebih tepat sosiolek.

Tidak sulit untuk menerima bahwa tuturan para mentri atau pejabat tinggi lainnya menunjukkan ciri yang khas yang membedakannya dari tuturan tukang becak atau sopir angkota atau mbak-mbak jamu gendong; tuturan mahasiswa tentu saja lain dari tuturan pemuda/I sebayanya yang bekerja sebagai pegawai kasar di pabrik, pembantu tukang bangunan, dsb., yang kebetulan hanya tamat belajar di level SLTP misalnya; juga tidak sukar mengenali perbedaan anak-anak dalam penguasaan bahasa pada umur 10 bulan, 18 bulan, 4 tahun, 12 tahun, 21 tahun; bahasa Indonesia orang-orang yang berlatar belakang bahasa ibu bahasa Sunda segera dapat dikenali kekhasannya bila dibandingkan denga bahasa Indonesia yang dituturkan oleh orang-orang Jawa Tengah, Batak, atau Bali; sementara itu ada kesamaan umum yang didapatkan pada bahasa Indonesia orang-orang yang beda suku tadi yang dapat dibedakan dari bahasa Indonesia yang dituturkan oleh etnis Indonesia Tionghoa, Arab, India, dst. Demikian pula perbedaan latar belakang ideology atau agama juga mudah dikenali. Orangorang komunis di Indonesia dulu mudah dikenali lewat sejumlah kata dan ungkapan yang cukup khas: gerwani, lekra, Inggris kita linggis, Amerika kita setrika,hai kawan, ikutlah berjuang dengan kami Anda tidak akan kehilangan apa-apa kecuali kehilangan belenggu kemiskinan; dari mulut umat hindu bisa diharapkan munculnya kata-kata: Hyang Widhi Wase, Dewa-Dewi, om swasti astu, dst. ; di lingkungan orang Muslim, termasuk orang-orang nonMuslim yang tinggal di tengah-tengah Muslim, cukup sering, dalam bahasa Indonesia mereka, muncul kata-kata: insyak Allah, alhamdulilah, amin, Allah Hu Akbar, inallilah ..., dst.; Orangorang Kristen juga bisa dikenali lewat kosa kata mereka seperti, syalom, helleluya, puji Tuhan, kemurahan Tuhan, Juru Selamat umat manusia, Immanuel, filea, agape, dst.

Ketika perhatian terhadap kekhasan tutur kata yang mencerminkan latar belakang penuturnya tadi ditingkatkan maka akan bisa dikenali kekhasan tadi tidak hanya pada kosa kata atau ideom-ideom tertentu melainkan juga dalam kesantunan berbahasa . Perihal yang disebut belakangan itu berkaitan dengan ajaran dan suri tauladan tokoh panutan yang diikutinya. Meskipun tidak berlaku untuk semua umat, mencontoh keteladanan tokoh yang diidolakan tadi bisa juga meliputi model pakaian (celana dan baju), penataan rambut atau penggunaan topi tertentu atau peci, blangkon, kerudung atau jilbab, Pemeliharaan rambut menjadi panjang atau malah pendek sekali, pemeliharaan jenggot, pemakaian perfum dengan aroma yang khas, dsb. Tentu tidak semua umat berleku demikian, ada kalanya hanya rohaniwannya saja. Penampilan 
yang demikian itu biasanya mudah sekali dikenali karena menjadi semacam pakaian /penampilan tradisional. Perhatikan pakaian Kyai, Pastor, Bikhsu, dsb.

Dalam kaitannya dengan kekristenan tokoh yang diidolakan atau yang diteladani umat adalah Yesus Kristus atau Isa Almasih. Perihal meneladani Yesus Kristus ini malah sebenarnya merupakan perintah atau sekurang-kurangnya anjuran yang tertulis dalam Kitab Suci Injil, 'Hendaklah kamu dalam hidupmu bersama, menaruh perhatian dan perasaan yang terdapat juga dalam Kristus Yesus' (Filipi 2:5). Pada bagian lain Rasul Paulus menulis sebagai berikut: 'Imitate me, then, just as I imitate Christ' (1 Cor. 11:1).

\section{Keteladanan Isa Almasih dalam Komunikasi}

Di dunia ini barangkali tidak ada agama yang semisioner agama Kristen dan Islam. Belakangan ini agama Budha menyusul menjadi missioner juga. Pada awalnya Budha tergolong missioner, bahkan agama ini berkembang pesat tidak di India melainkan di Cina, Jepang, Korean, Thaelan, Kamboja, Mianmar, dsb. Lalu dalam berabad-abad seolah-olah Budha tidak lagi misionar. Sekarang ini cukup mudah menemukan umat Budha di Eropa, Amerika, Australia, dan di Indonesia.

Dasar kemisioneran kekristenan antara lain adalah, apa yang dikenal sebagai, Amanat Agung yang diberikan oleh Isa Almasih sendiri, yang tercatat sebagai berikut: 'Isa Almasih mendekati murid-murid-Nya dan berkata, "Kepada-Ku telah diberikan segala kuasa di Surga dan di bumi. Karena itu pergilah, jadikanlah semua bangsa murid-Ku dan baptislah mereka dalam nama Bapa dan Anak dan Roh Kudus, dan ajarlah mereka melakukan segala sesuatu yang telah kuperintahkan kepadamu” '(Matius 28:18-20).

Di dalam kekristenan yang disebut Penginjil sejati atau misionaris dalam arti yang sesungguhnya adalah Isa Almasih sendiri. Dialah utusan Yahweh yang disebut-Nya Bapa itu; Dialah Firman-Nya yang telah menjadi manusia. Yesus membawa Khabar Baik atau Injil ke dunia ini. Khabar baik tentang Yahweh atau Yehova atau Elohim atau yang dalam bahasa Arab disebut Allah --setidaknya kata Allah itu digunakan oleh orang Kristen Arab bahkan sejak sebelum Islam ada. Khabar baik itu adalah tentang Yahweh yang mengasihi umat manusia, Yahweh yang menganjurkan umat untuk mengasihi Allah dengan segenap kemampuan dan mengasihi sesama manusia seperti mengasihi dirinya sendiri; mempercayai Isa Almasih sebagai Juru Selamat yakni dengan mempercayai karya agung-Nya yang mendamaikan Yahweh sendiri dengan umat-Nya yang berdosa. Selanjutnya tiap-tiap orang yang percaya diberi-Nya amanat agung untuk memberitakan Injil. Dan, pemberitaan Injil itu yang utama dan 
terutama adalah melalui tutur kata dan perilaku sehari-hari sebagaimana dicontohkan oleh Isa Almasih sendiri. Seperti apakah keteladanan yang diberikannya itu? Bagaimanakah Yesus atau Isa Almasih itu memberitakan Injil? Tentu jawabnya ada di dalam Al Kitab itu sendiri. Keteladanan itulah yang menjadi tolok ukur perilaku umat sehari-hari; keteladanan itulah sumber inspirasi santun bahasa umat. Jadi, pemaparan atau lebih spesifik lagi penjabaran keteladanan itu akan menghasilkan seperangkat prinsip yang pada gilirannya bisa dijadikan ukuran kadar kesantunan umat. Berangkat dari sini orang bisa melakukan penelitian, misalnya saja mulai dari tokoh-tokoh atau pun aktiviis gereja. Pendeknya, lalu, bagaimanakah para pengikut Isa Almasih itu seharusnya memiliki merk atau kekhasan dalam bersantun bahasa dalam kehidupan sehari-hari, bukan pada har-hari tertentu seperti hari Minggu misalnya, lebihlebih lagi di lingkungan gereja. Jadi, perhatian itu justru difokuskan pada saat mereka tidak sedang bertugas dalam waktu-waktu peribadatan.

Dalam bukunya yang berjudul Communication Theory for Christian Witness, Kraft (1981) melaporkan hasil pengkajiannya atas Injil, perihal bagaimana Isa Amasih mengkomunikasikan Injil lewat tutur kata dan perbuatan dalam hidup sehari-hari-Nya, sebagai berikut.

Tujuan utama Yahweh atau Allah menciptakan manusia adalah menciptakan partner yang segambar dengan-Nya, yang memungkinkan terjadinya komunikasi antara Dia dan ciptaanNya tadi secara unik. Kraft menulis bahwa,'God wants a relationship with the human beings he created' (hal.18). Hal itu terjadi karena Allah itu kasih; ada banyak sifat Allah akan tetapi, sehubungan dengan relasinya dengan manusia, sifat kasih-Nyalah yang menonjol. Hal ini mudah dipahami sebab Allah yang tidak sebanding dengan umat ciptaan-Nya; Allah yang dasyat itu tentu sangat mengasihi ciptaan-Nya. Pada hal kasih itu memerlukan objek sebagai sasarannya. Manusia adalah tempat limpahan kasih Allah. Tetapi, mengapa manusia bukan ciptaan yang lain? Kraft meneruskan, 'God reaches out to us to elicit a response to which the whole relationship is keyed' (hal. 19). Di mana-mana, ketika dijumpai masyarakat manusia, di situ pasti ada semacam agama, yakni kesadaran tentang adanya Yang Mahatinggi, yang peduli terhadap manusia, dan isi dari agama itu tak lain adalah respon manusia terhadap Chaliknya. Selanjutnya, Allah mempunyai agenda tertentu di dalam komunikasi itu yakni, 'God wants to be understood' (hal. 20). Mengenal Dia; mengenal jalan-Nya; mengenal kehendak-Nya. Allah menginginkan umat-Nya hidup dalam pemerintahan-Nya yang mendatangkan damai sejahtera Surgawi. Akan tetapi bagaimana yang Maha Tak Terhingga itu bisa berkomunikasi dengan umat-Nya yang fana dan terus berubah itu. Ada banyak cara: melalui wahyu umum (general revelation) yakni jagad raya yang serba tertata, teratur yang menghidupi mahluk yang ada di 
dalamnya membawa orang pada kesimpulan adanya sang penyelenggara di bail semua yang tampak; melalui para Nabi; dan akhirnya melalui Firman-Nya atau Kalimat-Nya yang turun ke dunia untuk menjadi manusia. Yang terakhir ini adalah puncak komunikasi. Dua model pewahyuan yang disebut terakhir itu disebut pewahyuan khusus.

Sehubungan dengan turunnya Firman atau Kalam ke dunia yang hidup di tengah-tengah manusia sebagai manusia sejati itu, Kraft menulis, 'It is nothing short of amazing that the God of all universe would choose our familiar turf, our way of life, our language, our total frame of reference rather than his own as that in terms of which he would interact with us' (hal.23). Dalam hal ini Allah melalui Firman-Nya bahkan telah demikian mempercayakan diri-Nya kepada mahluk ciptaan-Nya, '... makes himself dependent on and vulnerable to them' (ibid). Di sinilah kita mendapatkan prinsip yang pertama; yang dimaksud dengan frame of reference di atas tidak lain adalah kebudayaan (manusia), bahasa (manusia), kalas social, situasi kehidupan, dsb. Jadi dalam menjalin komunikasi ini strategi-Nya adalah receptor-oriented - by entering their frame of reference, by participating in their life-- agar bisa dipahami secara maksimal oleh parner komunikasinya yakni manusia.

Kraft menyebut prinsip-Nya yang kedua adalah personalness. Yang dimaksud dengan personalness di sini bukan hanya Firman itu berinkarnasi sebagai manusia, lebih dari itu, Isa Almasih, atau kepribadian-Nya adalah message, adalah pesan Allah itu sendiri atau dengan kata lain 'Bahasa-Nya (budaya-Nya) menunjukkan Firman-Nya'. Di sini menyatu antara keyakinan-Nya dengan ucapan dan tindakan-Nya. Ketika Isa Almasih berkata 'Datanglah kepada-Ku karena Aku lemeh lembut' itu bukan pernyataan kearogansian, sebab Dia memang demikian. Demikian juga ketika Paulus berkata, 'Imitate me, then, just I imitate Christ (1 Kor. 11: 1) sesungguhnya mesti dipahami sebagai perintah sekaligus pencerahan bahwa orang percaya atau umat Kristiani harus mempertanggungjawabkan keimanannya lewat konsekuensikonsekuensi yang tidak mungkin dihindari yakni berjuang untuk terus mengidentikkan dirinya dengan tokoh-tokoh panutannya yang dapat dilihat, diukur, atau dinilai dari perilaku dan tutur katanya oleh semua orang yakni sesamanya.

Semua orang yang membaca Injil dengan sungguh-sungguh dan dengan semangat objektif pula, akan sampai pada simpulan yang sama dengan Kraft bahwa, 'The God who is receptororiented and personal takes pains to see that his messages are presented with a high degree of empact' (ibid hal. 28). Untuk itulah Isa Almasih dan para murid-Nya mati-matian mempertahankan kredibilitasnya di masyarakat; selalu memperlakukan tiap-tiap mitra tuturnya secara spesifik yakni dengan memperhatikan latar belakang mereka sebagai konteks yang sangat penting dalam wewarah (pengajaran) Jawa disebut nguwongke (mengorangkan); tidak 
menggurui, dalam komunikasi, melainkan memfasilitasi saja, sampai akhirnya mitra tutur itu menemukan sendiri maksud tuturan penutur; dalam kejawen disebut menang kang tanpa ngasorake, dsb. Ada berlimpah contoh yang bisa ditemukan dalam Injil sehubungan dengan deskripsi di atas.

Bertolak dari penggambaran yang serba singkat perihal tatalaku Isa Almasih dan muridmuridnya dapatlah dijabarkan seperangkat parameter atau tolok ukur santun bahasa umat Allah atau lebih spesifik lagi umat Kristen yang pada gilirannya bisa dijadikan dasar penilaian pencapaian etika kebahasaan atau language propriety umat Kristiani.

\section{Keparalelan Santun Bahasa Indonesia dengan Santun Bahasa Umat}

Salah Satu alasan penulis untuk menyusun seperangkat kaidah yang mudah-mudahan berguna untuk meneliti atau pun mengkaji tingkah laku khususnya dalam bersantun bahasa orang-orang atau tokoh-tokoh umat beragama Kristen di Indonesia adalah adanya kesamaan atau kemiripan yang signifikan antara cara berkomunikasi Isa Almasih dan murid-muridnya tersebut di atas dengan simpulan hasil penelitian santun-bahasa Indonesia yang dilakukan oleh Prof. Soepomo Poedjosoedarmo ( Sosiolinguis Indonesia), seperti akan diuraikan berikut ini.

Adanya kemiripan santun bahasa sebenarnya tidak mengherankan sebab santun bahasa itu cenderung universal sifatnya. Setelah melakukan pengamatan dalam waktu yag cukup lama atas pemakaian bahasa Indonesia sehari-hari, Poedjosoedarmo menulis, "Although the principles of language etiquette are somehow universal in nature, it is certain that they are more valid for Indonesian community than for users of other lenguages' (1987:400). Tentu benar juga, sebagaimana telah dinyatakan di atas, bahwa di samping ada kesamaan antara santun bahasa yang bersumber dari agama tertentu mempunyai kemiripan dengan yang ada pada agama lain tetapi juga tidaklah sama persis. Kemiripan yang dimaksud itu merupakan khasanah yang universal sebab untuk apa yang disebut santun itu tentu sama yakni bahwa setiap orang yang terlibat dalam konversasi, demi kesantunan, harus selalu ingat agar tutur katanya dapat diterima secara menyenangkan oleh lawan tutur maupun segenap orang yang kebetulan ikut mendengar. ' ... what P1 says should please P2 and P3, or that at least it do not annoy, irritate or hurt the feelings of P2 and P3' (ibid. hal. 401). Demi tujuan tersebut maka jemaat Kristiani semestinya seperti idolanya, dalam menjalin komunikasi yakni selalu berorientasi pada mitra tuturnya, receptor-oriented. 
Untuk memenuhi prinsip yang pertama itu seorang pengikut Isa Almasih, yang pertama, bisa dilihat atau diukur dari, pertama, kesiapsediaan dan kegairahan atau kehangatan dalam bercakap dengan orang lain, Poedjosoedarmo merumuskan sebagai, 'show a friendly attitude by indicating that he is ready to communicate with P2' (hal.401); bukan saja menganggap percakapan itu penting melainkan juga bahwa lawan wicara itu adalah pribadi yang dianggap berharga untuk diajak bercakap tanpa pandang latar belakang social mereka. Ini bukanlah hal yang mudah sebab secara bawakan orang cenderung membeda-bedakan orang berdasarkan penilaian atas latar belakang orang yang diajak bercakap. Yang demikian itu hanya mungkin dilakukan apabila orang (Kristen) menyadari kegiatan sehari-harinya sebagai bagian dari pelayanannya (memperkenalkan Injil). Perlu dicatat bahwa menjadikan seseorang itu murid Isa Almasih tidak sama persis dengan mempengaruhi orang agar menjadi anggota Gereja. Kekhasan pada kekristenan dalam hal ini ialah sikap ramah dalam komunikasi ini harus ditunjukkan justru dengan prioritas kepada orang-orang yang bukan atau belum menjadi Kristen, adapun targetnya adalah menjadikan orang sebagai murid Isa Almasih. Nah, untuk kriteria yang pertama ini, berdasarkan pengalaman penulis, masih banyak tokoh-tokoh gereja yang tidak lulus di sini. Akan tetapi hipotesis semacam itu mesti dibuktikan lewat penelitian.

Mungkin baik untuk ditambahkan bahwa keramahan atau friendlyness model masyarakat Jawa bisa dipakai sebagai alat pembanding. Di Jawa ini biasa orang berkata, 'kapan mau dolan?', 'mau kemana?', 'wah, mborong-mborong ni', 'ayo mampir, itu mbakyumu ada di rumah. Yang di maksud dengan 'mbakyu' atau kakak perempuan di sini adalah istri penutur yang adalah orang lain (bukan saudara) lawan tutur. Boleh saja orang memandangnya dari sudut pandang lain, dan lalu berkata 'orang Jawa suka basa-basi', akan tetapi dari sudut santun bahasa, jelas contoh di atas perlu dilestarikan.

Siapapun orangnya di Indonesia ini cenderung senang ketika dipuji. Pujian itu bisa menciptakan suasana menjadi menyenangkan. Tersedia banyak sekali cara untuk memuji orang, seperti misalnya, 'wah cerah sekali (wajah Anda) hari ini', 'Anda tampak cocok dengan baju Anda ini', 'pertanyaan yang bagus tapi sulit dijawab', 'wah pandai benar kamu', dsb. Memuji orang itu sebenarnya tanpa modal akan tetapi besar sekali manfaatnya untuk menciptakan suasana komunikasi yang menyenangkan, akan tetapi masih sedikit orang Kristen yang menyadarinya.

Selanjutnya, yang kedua, tuturan santun yang berorientasi pada mitra tutur tentunya memilih varian bahasa atau kosakata yang dipahami karena memang dihayati atau digunakan 
dalam hidup sehari-hari mitra tuturnya. Varian bahasa/dialek/sosiolek/ tertentu yang digunakan orang terpelajar tentu berbeda dari yang kurang atau malah tidak terpelajar. Dalam hal bahasa/dialek/sosiolek Jawa misalnya juga mesti diperhitungkan soal speech level atau tingkat tutur yang hendak dipilih: ngoko atau kromo. Untuk yang disebut terakhir itu sebenarnya menyangkuti realitas hubungan antara penutur $(\mathrm{O} 1)$ dan mitra tutur $(\mathrm{O} 2)$. Hal yang demikian itu tentu saja tidak hanya berlaku untuk orang dengan latar belakang pendidikan saja, melainkan juga untuk latar belakang social (status social), latar belakang umur,latar belakang etnis, agama, dsb.

Prinsip yang kedua yang dicontohkan oleh Isa Almasih dan murid-murid-Nya yakni personalness atau kesediaan membaur sepenuhnya ke dalam dunia lawan tutur (Bandingkan Maxwell, 2004: 73-84) dan menjadikan penampilannya identik dengan khabar baik yang hendak diwartakannya membawa konsekuensi bahwa seorang Kristiani yang santun harus selalu sadar akan perlunya mengendalikan diri sewaktu terlibat dalam suatu tindak komunikasi. Dia atau mereka tidak boleh temperamental; bisa 'control himself and not easily lose his temper', demikian tulis Poedjosoedarmo (hal. 402). Seseorang yang mudah kehilangan control diri akan mendapat banyak kesulitan untuk menjaga agar tutur katanya tetap santun dan tetap berada dalam kekhasan varian tutur lawan tuturnya. Kata-kata kasar, tidak senonoh, umpatan atau kata-kata asing seperti bahasa Inggris misalnya yang tidak terpahami lawan bicaranya, bisa muncul di luar sadar. Perihal kontrol diri ini bisa tidak sama pada berbagai masyarakat tutur; orang Jawa, Sunda tentu berbeda dengan orang Batak misalnya. Sungguh pun begitu, di mana pun juga tentu dianggap tidak baik pribadi-pribadi seperti, pemarah, suka menghina, suka menyakiti hati, kekanak-kanakan, atau yang lain lagi. Selanjutnya, di samping prinsip yang pertama dan kedua, receptor-oriented dan personalness, seorang Kristiani harus meniru panutannya yakni harus menjagai agar tuturannya enak didengar. Untuk tujuan ini memang seseorang harus mampu menjaga kredibilitasnya di mata public; sabar dalam arti tidak menunjukkan sikap yang tergesa-gesa untuk mengakhiri pembicaraan, tidak menggurui, mempercayai lawan tuturnya, dsb. Prinsip yang ketiga ini adalah kesediaan kebersungguhan dalam mengupayakan efektivitas komunikasi.

Termasuk ke dalam jenis ini, yang perlu dihindari, ialah penampilan yang penuh dengan kepura-puraan. Dia atau mereka memang harus terus-menerus berjuang/bergumul agar apa yang dipikirkan, dituturkan dan dilakukan sesuai dengan yang diyakininya sehingga terwujutlah sikap yang konsisten; pada dasarnya tetap sama di mana dan kapan pun juga. 
Pendeknya, orang harus meyakini bahwa dirinya adalah surat yang terbuka bagi orang lain. Ketidakkonsistenan dan ketidakkonsekuenan, cepat atau lambat, pasti akan ketahuan.

Termasuk ke dalam prinsip ini pula ialah memilih strategi tutur yang memudahkan lawan wicaranya untuk memahaminya, mengatur agar volume suaranya tidak terlalu lemah atau terlalu keras, nada yang menyenangkan dan tentu saja diseling dengan humor yang pas, tidak menguasai pembicaraan, memberi kesempatan orang lain untuk berbicara juga, dsb. Penggunaan varian dan kosakata yang sesuai degan situasi tutur adalah hal lain yng juga perlu diperhatikan. Penggunaan varian bahasa dan kosakata dalam sebuah pesta tentu berbeda dengan situasi berkabung, situasi yang serba resmi atau formal tentu berbeda dengan yang serba santai atau akrap. Situasi di dalam kelas antara guru-murid juga berbeda dengan situasi di luar kelas. Semuanya itu yakni pilihan atau pilihan-pilihan itu tadi, dalam hal ini, mesti dilakukan atas dasar prinsip demi kenyamanan mitra tutur. Termasuk juga ke dalam tolok ukur ini adalah kesediaan dan ketrampilan dalam memilih topik pembicaraan, yakni topik atau topik-topik yang disukai oleh $\mathrm{O} 2$.

Di Indonesia ini bahasa Indonesia merupakan bahasa kedua. Di pedesaan malah masih didapati orang yang hanya bisa berbahasa daerah, sementara itu penutur bahasa Indonesia sebagai bahasa kedua ada yang sebatas bahasa formal (hasil belajar di sekolah), ada pula yang hanya menguasai bahasa remaja yang berbau kejakarta-jakartaan. Agar mudah dipahami penutur yang santun tentu memilih varian yang dikuasai dengan baik oleh mitra tuturnya. Isa Almasih menggunakan bahasa Yunani Rendah demi bisa menjalin komunikasi dengan banyak orang dan ada kalanya menggunakan bahasa Arami ketika situasi terutama lawan tuturnya menghendakinya demi efektivitas tadi. Di Indonesia, lebih-lebih di dalam masyarakat Jawa kepekaan terhadap status orang itu tinggi. Padahal bahasa itu bukan hanya sekedar alat komunikasi melainkan juga sebagai penanda corak hubungan antapenutur berdasarkan status mereka. Bertutur terhadap orag yang lebih tua berbeda dengan orang yang seumur dan berbeda lagi dengan mereka yang lebih muda. Salah memilih varian ini bisa menimbulkan efek tidak menyenangkan.

Efek tidak menyenangkan juga bisa timbul ketika ucapan orang itu tidak jelas. Tidak jelas bisa karena kurang keras atau terlalu lemah, bisa juga karena bahasa Indonesia seseorang itu mempunyai logat khusus yakni sangat dipengaruhi oleh bahasa pertama atau bahasa ibunya. Sebaliknya bahasa Indonesia logat khusus itu ada kalanya justru sangat cocok ketika $\mathrm{O} 2$ adalah orang atau orang-orang yang sedaerah asal. Sebagai contoh, ada seorang pengkhotbah yang 
sangat populair di Semarang atau tempat lain karena menggunakan bahasa Indonesia dielek Melayu Tionghoa ya karena kebetulan pendengarnya itu sebagian besar orang Indonesia Tionghoa yang menggunakan dialek Melayu sebagai bahasa keakraban. Dengan bahasa keakraban ini peluang untuk menyisipkan humor-humor yang khas dan beken menjadi besar. Pada hal pemanfaatan humor juga merupakan salah satu strategi agar tutur atau cakapannya menjadi menyenangkan dan tentu menjadi lebih efektif.

Ada orang-orang tertentu yang tidak menyenangkan untuk diajak bercakap-cakap. Pada hal tidak sedikit orang yang tahu bahwa bercakap-cakap itu bisa menjadi salah satu kenikmatan dalam hidup ini. Tetapi, tujuan itu bisa tidak tercapai ketika, misalnya saja, salah satu peserta tutur itu cenderung menguasai percakapan; kurang member kesempatan kepada mitra tuturnya untuk berkontribusi dalam percakapan tadi. Juga tidak menyenangkan ketika topic pembicaraan itu selalu menyangkuti diri penuturnya (o1) lebih-lebih ketika topic itu ujungujungnya hay untuk menunjukkan kehebatan, keberuntungan, kepandaian, kekayaan O1. Banyak orang kaya, orang terdidik atau yang lain yang terperosok ke dalam model bercakap yang egois seperti itu ketika lawan wicaranya orang yang serba sederhana atau rendah status sosialnya.

Penutur santun tentu juga akan memperhatikan situasi tutur. Di dalam suatu perkabungan tentu orang diharapkan tidak bercakap terlalu keras, tertawa cekikikan, mengeluarkan kata-kata makian. Di dalam sebuah pesta ulang tahun misalnya, tentu tutur kata dan pilihan kosa kata yang sebaliknya yang diharapkan: gelak tawa, tegur sapa yang disertai pujian, ekspresi yang berseri-seri, dsb. Di sini topic pembicaraan pun harus yang sesuai. Percakapan antara bos dengan anak buah, guru-murid, pendeta-jemaat harus selalu berubah sesuai dengan realitas situasi yang sedang ada, artinya tidak selalu sama dengan situasi kerja, situasi di kelas, dan situasi formal di Gereja atau di Masjid, Wihara, Candi, dsb.

\section{Penutup}

Tidak serta merta orang yang berkehendak menjadikan dirinya sama dengan tokoh idolanya akan bisa mewujutkan keinginannya. Imitasio Kristy atau mengikuti jejak Kristus memang harus menjadi kebulatan tekat orang Kristen akan tetapi untuk mencapai ke sana itu adalah pergulatan atau pembelajaran sepanjang hidup. Keadaan yang demikian itu berlaku untuk umat agama atau ideology apa pun. Merasa sudah berhasil atau sudah benar justru menjadi tanda kegagalan yang amat jelas. Belajar seumur hidup, melakukan reinterpretasi lewat sikap kritis terhadap diri dan milik sendiri justra menjadi tanda kematangan. 
Kekristenan tidak harus sama di seluruh dunia meskipun sudah tentu kesamaan itu ada. Orang Indonesia hendaknya tetap orang Indonesia ketika dia menjadi Kristen, Islam, Budha, Kong $\mathrm{Hu} \mathrm{Chu}$, atau yang lain. Demikian pula untuk orang Singapura, Thailan, Argentina, Nigeria, Pakistan, dsb. Dengan demikian, santun bahasa orang Kristen Indonesia tentulah Kristiani akan tetapi sekaligus juga Indonesia. Dalam hal ini, secara lebih luas, mesti dikatakan bahwa kekristenan Indonesia haruslah kekristenan yang terinkulturasi ke dalam budaya Indonesia. Tentu saja kajian seperti ini akan menarik untuk dilanjutkan pada, misalnya saja, makanan, pakaian, rumah, rumah ibadah, dsb., yang agamis (menurut agama tertentu) namun juga khas Indonesia.

\section{DAFTAR PUSTAKA}


Kraft, Charles H. 1981 Communication Theory of Christian Witness. Nashville: Abingdon Press.

Martin, J. R. and Rose, David. 2003 Working With Discourse, Meaning Beyond The Clause. London: Continuum.

Maxwell, John C. 2004 Winning With People. Diterjemahkan oleh Hariono S. Imam. Jakarta: PT Gramedia.

Poedjosoedarmo, Soepomo. 1987 'Language Ettiquette in Indonesia' dalam Spectrum, Essays Presented toSutan Takdir Alisjahbana on His Seventieth Birthday. Jakarta: Dian Rakyat.

Richards, Jack and Platt, John and Weber, Heidi. 1985. Longman Dictionary of Applied Linguistics. Great Britain: Richard Clay. (The Chaucer Press) Ltd.

Tim Penerjemah LAI. 2008 Alkitab, Terjemahan Baru/New International Version. Jakarta: Lembaga Alkitab Indonesia. 